\title{
Technology as a Pillar for Essential Oil Green Extraction
}

\author{
Carlos Machado ${ }^{1 *}$, Herman Lepikson ${ }^{1}$, Matheus Andrade ${ }^{1}$, Yasmim Thasla ${ }^{2}$, Sara Santos ${ }^{3}$ \\ ${ }^{1}$ Senai Cimatec University Center, GETEC; ${ }^{2}$ Federal University of Bahia; ${ }^{3}$ Senai Cimatec University Center; \\ Salvador,Bahia, Brazil
}

\begin{abstract}
This paper focuses on essential oil (EO) extraction via steam distillation and the technological possibilities to enhance both operational and environmental performances. Steam distillation is the most common extraction method (93\% of the worldwide volume), the opportunities in these production systems become a concrete target for improvements and are reflected in the businesses overall results. This paper brings the green extraction approach and the technology upgrade as an evolutionary path for this industry. A real process conception, in its current technology level, was assessed under the light of digital technology focus in order to enhance process effectiveness both in terms of material and energy balances, with direct effects over environmental performance and quality.
\end{abstract}

Keywords: Essential Oils. Green Extraction. Digital Technology.

\section{Introduction}

The remarkable growth of the natural products market is justified by consumers' movement from industrialized food to natural products. The plant extracts market size reached US\$ 23.7 billion in 2019, projecting US\$ 59.4 billion by 2025 , according to marketsandmarkets.com [1]. The essential oils (EO) market size, part of this value, is mentioned by alliedmarketsearch.com [2] as US\$ 8 billion in 2018, reaching approximately US\$ 16-17 billion by 2026 .

Green extraction principles subsidize the pursue of a more efficient process with a reduced number of unit operations, optimized process time, energy requirements, and minimum or zero waste generation. This industry segment comprises a myriad of small producers, without access even to basic technology developments [3, 4].

Figure 1 shows the six green principles [4] applied to inputs and outputs of an extraction

Received on 18 September 2020; revised 15 December 2020. Address for correspondence: Carlos Machado, Orlando Gomes Avenue, 1845 - Salvador, BA, 41650-010, Brazil, (55) (11) 98371-4444; carlos.tosta@uol.com.br. Article selected from VI International Symposium on Innovation and Technology (SIINTEC).

J Bioeng. Tech. Appl. Health 2021;4(1):9-16.

(C) 2021 by SENAI CIMATEC. All rights reserved. process, with direct impact over environmental performance but with ultimate effect on efficiencies and business overall results, including financial margins, when optimized.

Digital technology, lately under the label industry 4.0, when properly applied, is a set of tools capable to accomplish the green principles proposals [5]. The essential oil extraction industry still needs attention in the basic engineering aspects, such as energy recovery, efficient thermal insulation, and pre-heating capabilities [6]. Nevertheless, the focus of this paper is to point out opportunities attached to technology updates, serving as a watch out for those in charge of production administration and/or company owners, with evident impact on environmental performance. So, from the plant floor reality to the upper management levels, the control, monitoring, and management of the essential oil extraction industry is a concrete subject for this renewal wave, meaning that operational and environmental excellence cannot exist without these attributes. In Figure 2, the evolution from conventional to the new technologic trend is shown in three levels: the first operates at shopfloor and it is represented by the sensors, the programmable logic controller (PLC), and process control level (SCADA - Supervisory, Control, and Data Acquisition system. The second level (plant management system), the Manufacturing 
Figure 1. Green principles applied to extraction processes.

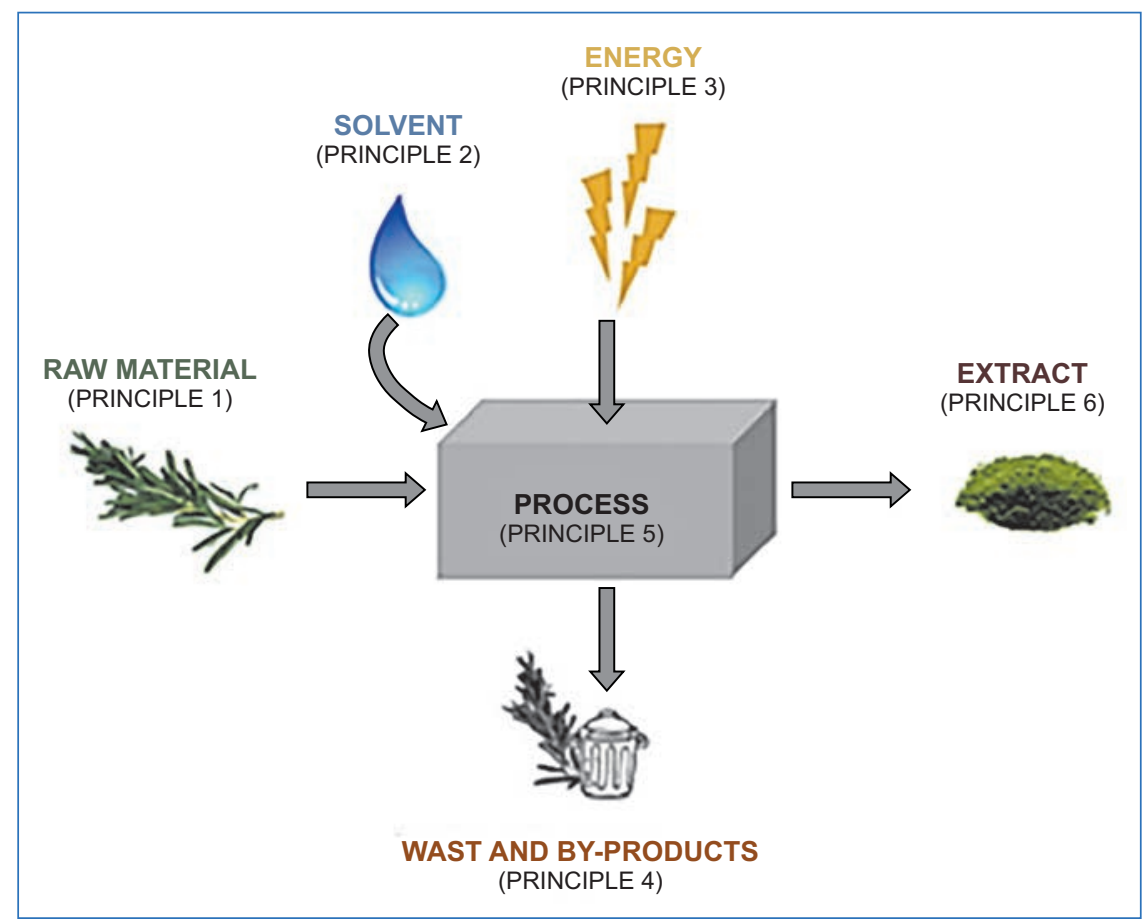

Adapted from Chemat [4].

Figure 2. Evolution: from conventional to 4.0 configuration.

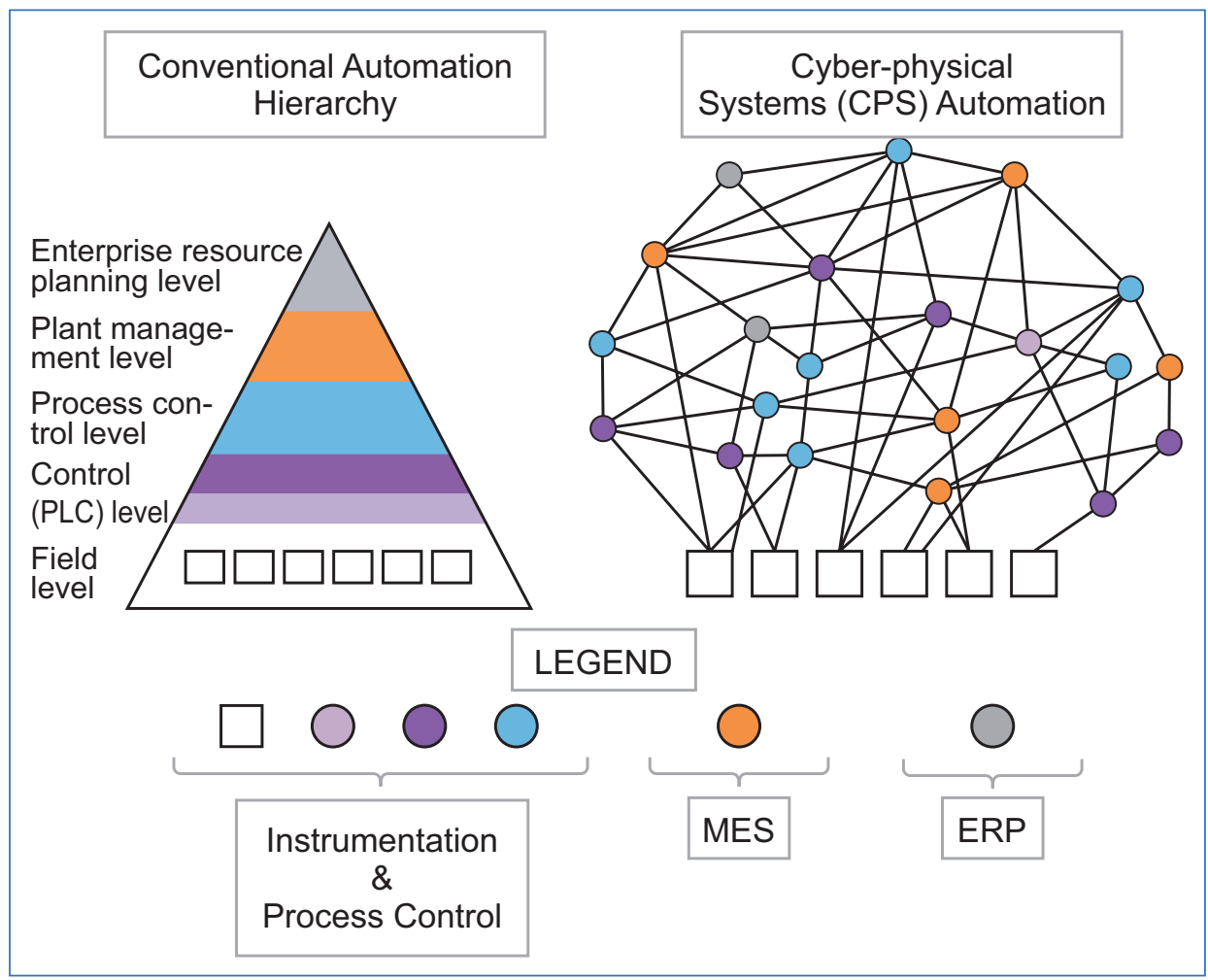

Adapted from www.foodengineeringmag.com [7]. 
Execution System (MES), connects all productive activities to the Enterprise Resource Planning (ERP), which is the third one. ERP consists of the company's financial and organizational areas, for management purposes [7]. MES can be considered the enabler to administrate the manufacturing 'in progress', step by step and in real-time: overall manufacturing control, time-to-market, overall manufacturing visibility, capacity allocation, and other capabilities. MES evolution, within the 4.0 scenario, is integrated into the so-called cyberphysical space (CPS), where multilevel virtual and real worlds are merged [8].

Table 1 reflects some of the technological possibilities applicable to the six green principles, enlightening but not restricting the objectives of the present paper. The columns are connected from left to right, demonstrating - through the arrows the way the basic systems subsidize the next ones.

Each business has its own peculiarities and direction for investments in new technologies. Financial analysis indicates the best options and their impact on business results: ROI - return on investment; NPV - net present value, among other analysis tools, encompassing the business with competitiveness. Therefore, the objective of this work is to unveil technology possibilities as a leap toward operational excellence for the essential oil extraction industry, applied to a real process, owned by Linax Indústria e Comércio de Óleos Essenciais Ltda.

The organization readiness must be assessed in terms of maturity to support such breakthrough. People must be prepared with proper skills and training. Bill Gates reinforces that: "the first rule of any technology used in a business is that automation applied to an efficient operation will magnify the efficiency. The second is that automation applied to an inefficient operation will magnify the inefficiency", meaning that the more developed is the organization the broader is the reach of the investments [9]. In this sense, Table 1 highlights the objective of this paper, presenting possibilities and bridging the green principles and technology, as a strategical lever for both academic and industrial developments.

\section{Material and Methods}

The methodological steps are outlined as described below:

- Starting point: status of the process in its current conception, within Linax company

- Steps for technology improvements:

- Basic Instrumentation and plant floor level control via PLC.

- Monitoring via SCADA.

- MES and ERP.

Essential oil extraction system, as commonly operated by the company Linax, works under usual basic conditions (Figure 3). Then, the extraction operation consists of applying steam to a green mass through the extraction vessel and a postcondensation and separation, in a "blind" process, performed without sensors and monitoring systems, meaning that the control tasks are restricted to producers' manual actions based on their historic experience. This weak technological scenario delivers variable quantities and quality, high energy requirements, and equipment idling due to unprepared production sequences and planning. The environmental performance suffers the consequences of this lack of control, representing a large field of opportunities for improvements. The understanding of the process "as is" allows the identification of weaknesses and propositions discussed in the sequence of this article.

Basic Instrumentation and Plant Floor Level Control

Figure 4 shows a basic proposition for instrumentation, according to ISA [11] as the first step to improve control, when compared to the absolute simplicity of the original design (Figure 3).

Instrumentation and control enable material and energy balance improvements as well as optimize process time and repeatability, with direct effect on environmental performance and quality. 
Table 1. Technological possibilities applied to EO industry.

\begin{tabular}{|c|c|c|c|}
\hline & $\begin{array}{l}\text { Instrumentation } \& \\
\text { Process Control }\end{array}$ & Big Data \& Analytics & $\begin{array}{l}\text { Simulation \& Machine } \\
\text { Learning }\end{array}$ \\
\hline $\begin{array}{l}\text { Raw Material } \\
\text { (Principle 1) }\end{array}$ & $\begin{array}{l}\text { Analytical Values for } \\
\text { humidity, apparent } \\
\text { density, targeting yield } \\
\text { improvement. }\end{array}$ & $\begin{array}{l}\text { Data is intelligently } \\
\text { analyzed to find } \\
\text { correlations and } \\
\text { determining } \\
\text { parameters for self- } \\
\text { configuration. }\end{array}$ & $\begin{array}{l}\text { Self-configuration } \\
\text { parameters are optimized } \\
\text { by advanced simulation } \\
\text { like digital twin. The } \\
\text { proposed parameters will } \\
\text { reduce batch time, idling, } \\
\text { energy consumption. }\end{array}$ \\
\hline $\begin{array}{l}\text { Solvent } \\
\text { (Principle 2) }\end{array}$ & $\begin{array}{l}\text { Steam process variables } \\
\text { impact extraction } \\
\text { efficiencies (yield). } \\
\text { Variations cause } \\
\text { undesired effects as the } \\
\text { channeling [10] }\end{array}$ & $\begin{array}{l}\text { The best configuration } \\
\text { for steam parameters } \\
\text { will be determined for } \\
\text { next batches. }\end{array}$ & $\begin{array}{l}\text { Simulation proposes } \\
\text { fine adjustments via } \\
\text { machine learning. These } \\
\text { optimized parameters } \\
\text { can be fed into the } \\
\text { control system for next } \\
\text { batches. }\end{array}$ \\
\hline $\begin{array}{l}\text { Energy } \\
\text { (Principle 3) }\end{array}$ & $\begin{array}{l}\text { Sensors and control for } \\
\text { steam and cooling water } \\
\text { loops. }\end{array}$ & $\begin{array}{l}\text { Best configuration for } \\
\text { setpoints and process } \\
\text { times. }\end{array}$ & $\begin{array}{l}\text { Simulation indicates best } \\
\text { values for steam and } \\
\text { cooling water. }\end{array}$ \\
\hline $\begin{array}{l}\text { Waste \& by products } \\
\text { (Principle } 4 \text { ) }\end{array}$ & $\begin{array}{l}\text { Solid and liquid } \\
\text { residues (hydrosol) } \\
\text { can be analyzed and } \\
\text { commercialized as } \\
\text { valuable products. }\end{array}$ & $\begin{array}{l}\text { Composition of } \\
\text { Essential oil and } \\
\text { hydrosols indicate } \\
\text { process trends for } \\
\text { cooling water and } \\
\text { time of residence } \\
\text { parameters. }\end{array}$ & $\begin{array}{l}\text { Composition of } \\
\text { hydrosols in condensed } \\
\text { water is predetermined } \\
\text { from raw materials and } \\
\text { process conditions. }\end{array}$ \\
\hline $\begin{array}{l}\text { Process } \\
\text { (Principle 5) }\end{array}$ & $\begin{array}{l}\text { Sensors for all variables } \\
\text { inside/outside the } \\
\text { extraction vessel are } \\
\text { relevant to detect } \\
\text { undesired conditions. }\end{array}$ & $\begin{array}{l}\text { Process data is } \\
\text { valuable to feed real } \\
\text { tome simulators as } \\
\text { well as to determine } \\
\text { correlations. }\end{array}$ & $\begin{array}{l}\text { Real time process } \\
\text { simulators (digital twin) } \\
\text { detects deviations from } \\
\text { ideal process behavior. }\end{array}$ \\
\hline $\begin{array}{l}\text { Product (Extract) } \\
\text { Principle } 6\end{array}$ & $\begin{array}{l}\text { Instruments to determine } \\
\text { quality analysis of the } \\
\text { finished product and } \\
\text { quantitative indicators } \\
\text { (yield). }\end{array}$ & $\begin{array}{l}\text { Statistic treatment } \\
\text { to find correlations } \\
\text { between raw material, } \\
\text { process conditions and } \\
\text { the quality indicator of } \\
\text { the EO. }\end{array}$ & $\begin{array}{l}\text { Process parameters are } \\
\text { continuously improved } \\
\text { when correlations are } \\
\text { identified. }\end{array}$ \\
\hline
\end{tabular}


Figure 3. Essential oil extraction original status: without sensors and controls.

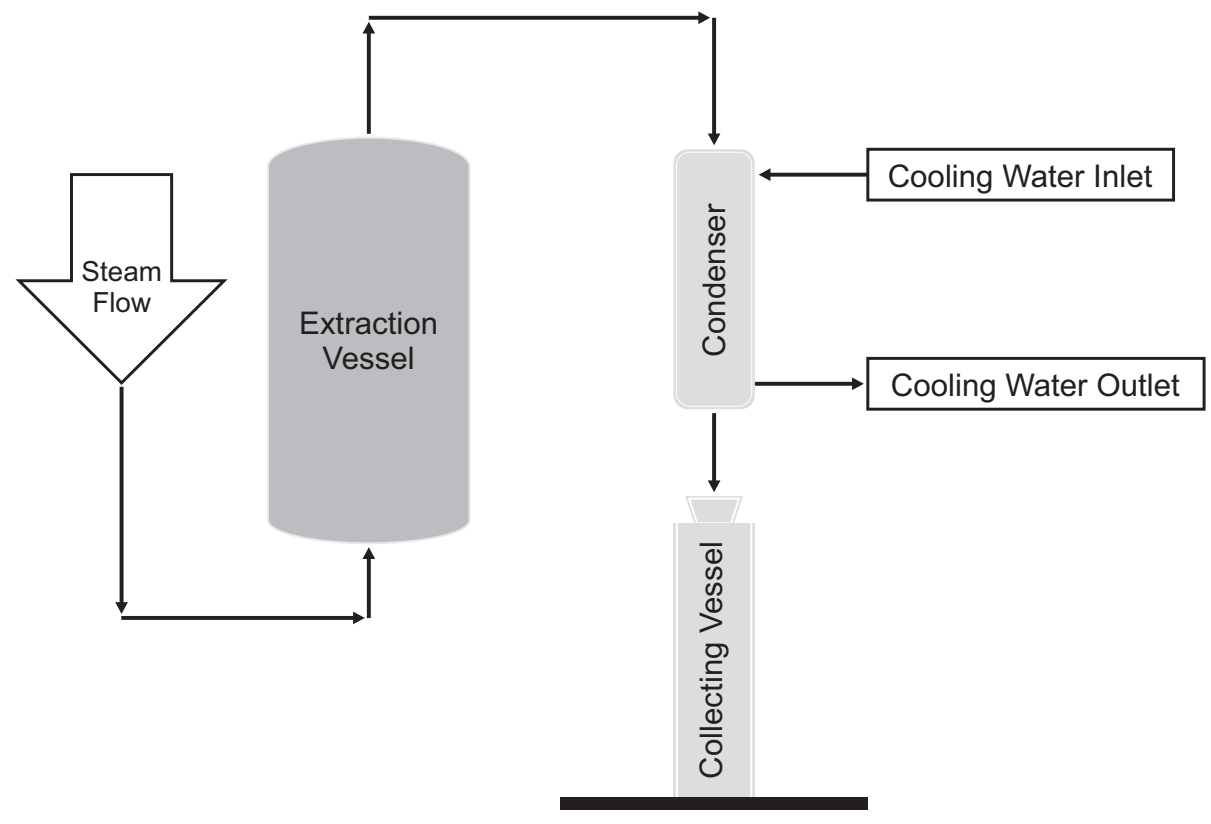

Figure 4. Essential oil extraction process with basic instrumentation.

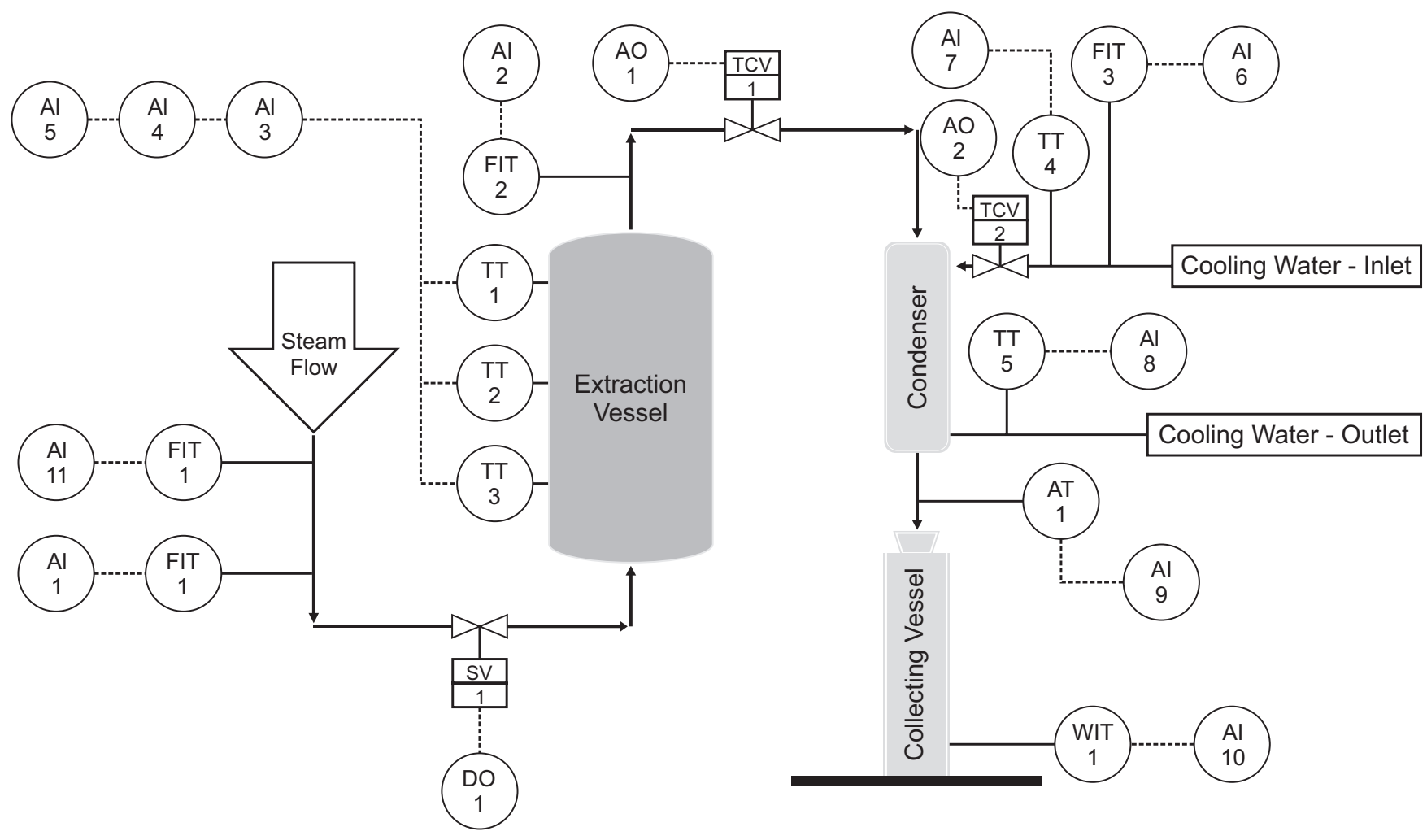


Monitoring: SCADA - Supervisory, Control, and Data Acquisition System

Beyond the plant floor level (Figure 4), there are countless possibilities for controlling, monitoring, and managing the essential oil extraction process. Figure 5 shows how EO plant floor structure could be connected into a 4.0 proposition [7], using a SCADA system, which can either connect plant floor operation with upper systems or, staying in this level with a richer MMI - ManMachine Interface and friendly access to process parameters, receipts, and historic data.

\section{$\underline{\text { MES and ERP }}$}

A complex manufacturing structure requires systems with broader scope for management purposes. For example, companies with a multifactory structure, geographically distributed, part of a cooperative mode (Figure 6) can interconnect facilities to better serve business purposes as well as customer's expectations [8].

The complexity and the set of choices depending on the selection of the right investment, proper planning activities, and excellent installation.

\section{Results and Discussion}

Technological enhancement possibilities for the EO extraction industry can significantly and positively impact quantities, extraction time and energy consumption through steam distillation. These improvements start in the plant instrumentation and control design, following to data acquisition and analysis, process simulation,

Figure 5. Example control, monitoring, and management configuration for EO.

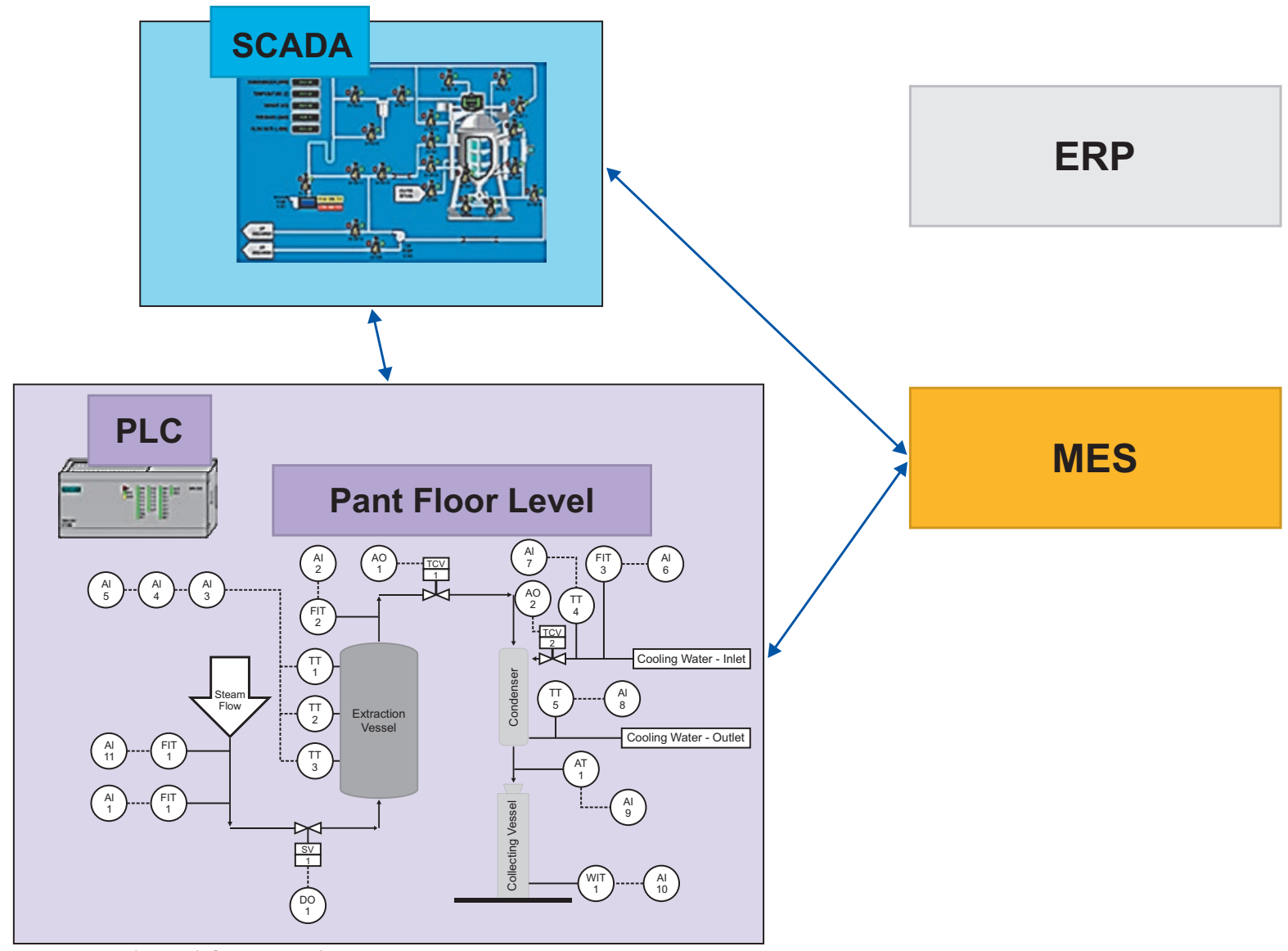

Source: Adapted from mechatrone.com. 
Figure 6. Multi-Factor structure view.

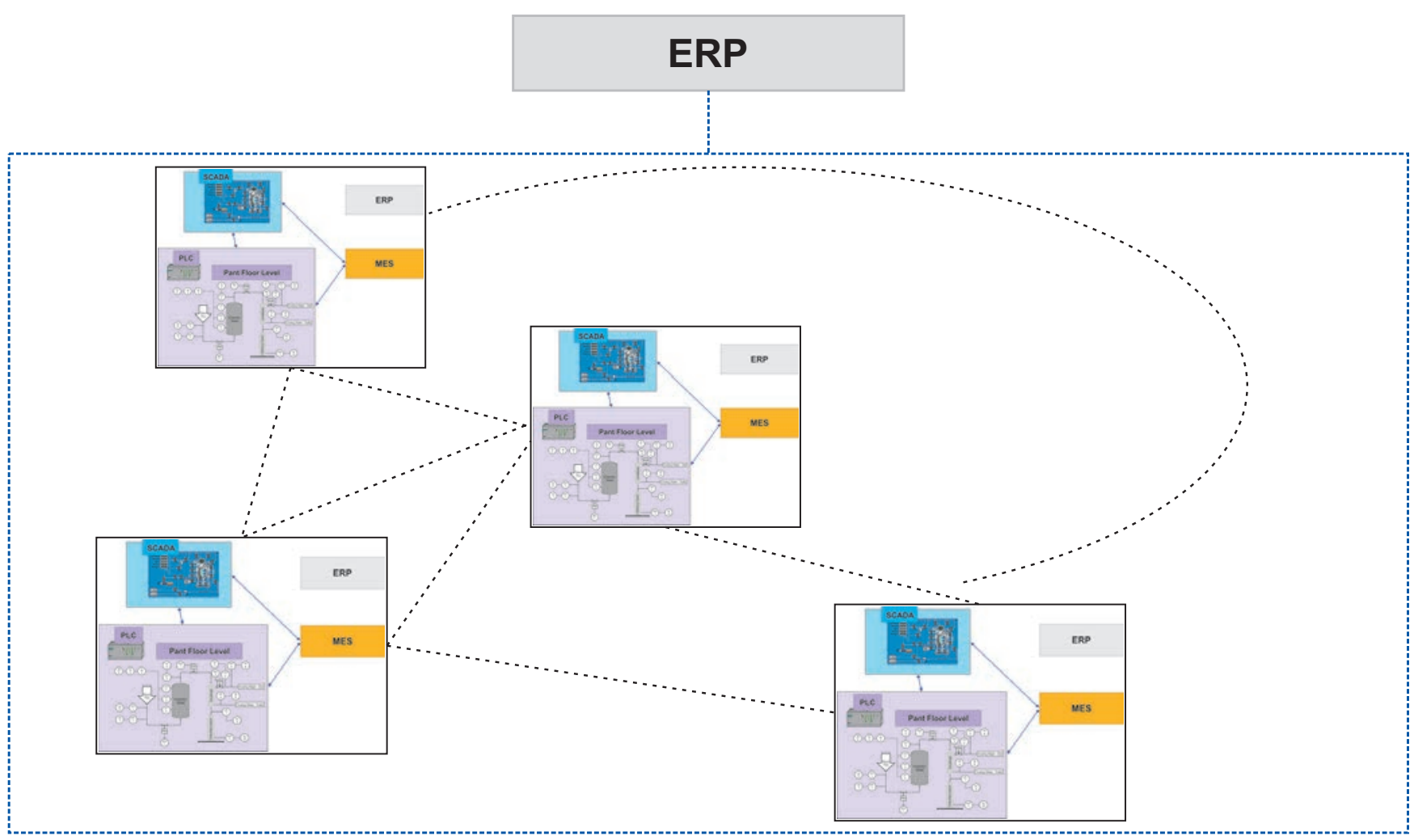

and machine learning which generates optimized parameters [13]. The possibilities brought in this paper aims at motivating readers to pursue the technological transformation in the extraction industry and continuous process improvement within organizations constantly developed to deliver customer, business, people, and better environmental results [3]. Steam distillation method can benefit from such technological advances and, as it uses water as a solvent, become one of the most environmentally friendly methods of extraction [4].

The innovation will add value and structure the business perpetuity as well as environmental performance. Green extraction processes are those qualified to consume less solvent (water) and energy, diminish waste generation and reduce or eliminate environmental impacts, in parallel to the benefits in the business bottom line: all in line with the industry 4.0 menu of possibilities.

The improvements explored in this paper are just a starting point for a profitable journey.
Application of renewable energy, minimization of product quality degradation, better use for subproducts like the condensate (hydrosols) and solid matter remaining from the extraction cycle are side by side with robust control, monitoring, and management systems in the relentless quest for environmental care industry performances.

\section{Conclusion}

The extraction industry of essential oils presents excellent opportunities for technology updates, aiming at better yields, optimized energy consumption, and minimum waste generation. The search for operational excellence consists of a set of actions and projects, both technological and organizational, that will impact the business overall: safety, quality, reliability, good manufacturing practices, costs, and the reduction or elimination of environmental impacts, focus of this paper, reaching the level of what can be called green extraction. 
The wave 4.0 brings a comprehensive portfolio of ideas to be converted into projects, enablers for better yields, quality, capacity management, and energy efficiency, as well as a considerable improvement in environmental performance.

\section{Acknowledgments}

Authors are grateful to LINAX Óleos Essenciais Ltda. and for the financial support from the BAHIA STATE RESEARCH FOUNDATION - FAPESB for the research grant awarded (5633/2019).

\section{References}

1. www.marketsandmarkets.com/Market-Reports/plantextracts-market-942.html 2020.

2. www.alliedmarketresearch.com/essential-oils-market 2020.

3. Chemat F, Vian MA, Cravotto G. Green extraction of natural products: concept and principles. International Journal of Molecular Sciences 2012;13(7):8615-8627.

4. Chemat $\mathrm{F}$ et al. Green extraction of natural products. Origins, current status, and future challenges. TrAC Trends in Analytical Chemistry 2019;118:248-263.
5. $\mathrm{Xu} \mathrm{LD}, \mathrm{Xu} E L, \mathrm{Li}$ L. Industry 4.0: state of the art and future trends. International Journal of Production Research 2018;56(8):2941-2962.

6. Masango P. Cleaner production of essential oils by steam distillation. Journal of Cleaner Production 2005;13(8):833-839.

7. www.foodengineeringmag.com/articles 2020.

8. www.smartindustry.com/articles/2016/the-evolutionof-manufacturing-execution-systems.

9. Chiarini A, Kumar M. Lean Six Sigma and Industry 4.0 integration for Operational Excellence: evidence from Italian manufacturing companies. Production Planning \& Control 2020:1-18.

10. Machado CAT, de Abdrade MAN, Lepikson HA. Manufacturing 4.0: Discussion on Application in the extractive industry of essential oils. Journal of Bioengineering and Technology Applied to Health 2019;2(3):86-91.

11. ANSI/ISA-5.1-2009 - Instrumentation Symbols and Identification 2009; [S.I.].

12. Filly A et al. Water as a green solvent combined with different techniques for extraction of essential oil from lavender flowers. Comptes Rendus Chimie 2016;19(6):707-717.

13. Litvinova OM, Levachkova YV, Chushenko VM. Determination of the critical parameters of the technological process control for pessaries with acyclovir and essential oils during industrial production. Social Pharmacy in Health Care 2017;3(4):59-64. 